\title{
EFFECTS OF APPLYING DEICING SALT TO ROADS IN PROTECTED AREAS: A PRELIMINARY STUDY IN THE BAVARIAN FOREST NATIONAL PARK
}

\author{
ZDENKA KŘENOVÁ ${ }^{1, *}$, ZDEŇKA CHOCHOLOUŠKOVÁ², \\ and VLADIMÍR ZÝVAL ${ }^{3}$ \\ ${ }^{1}$ Global Change Research Centre AS CR, v.v.i., Department of Biodiversity Research, Na Sádkách 7, 37005 České Budějovice, \\ Czech Republic; Faculty of Science, University of South Bohemia, Branišovská 31, 37005 České Budějovice, Czech Republic \\ ${ }^{2}$ Department of Biology, Faculty of Education, University of West Bohemia in Plzeň, Univerzitní 8, 30614 Plzeň, Czech Republic \\ ${ }^{3}$ GeoVision s.r.o., Částkova 1977/73, 32600 Plzeň 2 - Slovany, Czech Republic \\ *Corresponding author: krenova.z@czechglobe.cz
}

\section{ABSTRACT}

The negative effects of applying deicing salts to ecosystems are well documented for many countries. In some countries, the application of the deicing salts to roads in protected areas is prohibited by law. There is little detailed knowledge of the effects of deicing salts on ecosystems in the Bavarian Forest NP. The first preliminary study was conducted in 2011 and the first results are published in this paper. Nine permanent study sites were established and significant differences in soil chemical parameters among the different sites were recorded. The highest amounts of $\mathrm{Na}^{+}$and $\mathrm{Cl}^{-}$ions were recorded at study site \#4, which is located only a few meters from the bank of the Grosse Ohe River. Much higher concentrations of $\mathrm{Na}^{+}$and $\mathrm{Cl}^{-}$ions were found at 10 meters from the road than at the road edge and it is assumed that this is due to long-term contamination from water accumulating from melting snow. There were also higher concentrations of salt ions recorded at other sites along the main road. It is important that trajectories of the mobility of ions, including seasonal variability and commutations of salt in ecosystems, should be studied in future.

Keywords: road salting, halophytes, national park, ecosystem

\section{Introduction}

The negative effects of applying deicing salts to ecosystems are well known and documented for many countries, both in urban and natural areas (Findlay and Kelly 2011). In cold regions, deicing salts applied to roads are a major contributor to local and regional contamination, while salts from water softeners and septic systems are less important. There is emerging evidence that simple salt $(\mathrm{NaCl})$, the most often used deicing salt, contrary to what was previously thought is not transported rapidly through the soil and groundwater. This is also supported by the results of several mass balance and modeling studies. The retention via several mechanisms means that the flushing-out of winter-applied salts does not occur, and high concentrations may be present during summer when biological activity is high. This can affect the living conditions of water organisms, especially their most sensitive developmental stages. Several studies document the negative cumulative effects on amphibians breeding in vernal pools near roads (Karraker et al. 2008). Denoel et al. (2010) report no effects on mortality or growth of amphibians but a reduction in the speed of movement of tadpoles at sites where there is a high concentration of salt. High concentrations of salt affect competition and predation and also cause significant changes in plant (i.e. Angold 1997; Richburg et al. 2001; Wrobel et al. 2006) and soil invertebrate communities (Rusek and Rusek 1999).

The effects of $\mathrm{NaCl}$ can be summarized as:

- soil liquids (with $\mathrm{Na}^{+}$) on the leaves of plants reduce assimilation are blocked), dehydrate and irreversibly destroy plant tissues resulting in the leaves/needles turning yellow;

- increasing the concentration of ions $\left(\mathrm{Na}^{+}, \mathrm{Cl}^{-}\right)$in soil stresses plants by making it more difficult for them to take up and transport water by osmosis and transpiration;

- effect on vegetation: changes in species composition local gaps in vegetation cover, later also an increase in halophytes and sub-halophytes, which produce many seeds and invade neighbouring plant communities; in forests the killing of trees can decrease the stability of the forest;

- species diversity of soil microorganisms is affected;

- contamination of waterbodies has a negative effect on amphibians, pearl mussels etc.

In some countries, for example the Czech Republic, the application of deicing salts to roads in protected areas is prohibited by law. In Šumava National Park, the nearest trans-boundary partner of the Bavarian Forest NP, there are special exceptions for several main roads, where deicing salts are applied but only when particular conditions prevail. The monitoring of the effects of deicing salt on ecosystems in the Šumava NP was started in 2003, but the first monitoring was carried out in already the 1990s.

There is little detailed information on the effects of deicing salts on ecosystems in the Bavarian Forest NP. This, the first preliminary study was carried out in 2011.

The main goals of this preliminary study were:

1) To survey the ecological conditions along the "Nationalparkstrasse" road, the main road in the eastern part of 
Bavarian Forest NP and identify suitable study sites for monitoring the effects of deicing salt.

2) To establish permanent study sites.

3) To test the methodology and make the first analyses of the vegetation, soil structure and soil chemistry.

4) To prepare a monitoring program.

\section{Methodology}

\section{Study area}

The Bavarian Forest National Park is situated in the German part of the Bohemian Forest and is contiguous with similar forests in the Czech Republic. This forest landscape is one of the largest in Central Europe and covers the highest ridges of the low mountain range that forms the watershed between the Danube and Elbe catchment areas. The Bavarian part of the Bohemian Massif is called the Inner Bavarian Forest. The Bavarian Forest National Park (24,235 ha) is located in the center of the Inner Bavarian Forest and is about $98 \%$ covered by forest (Elling et al. 1987). The peat bogs are the second most important habitat in this area.

The region is characterized by montane and high montane areas within a vertical range of approximately $800 \mathrm{~m}$ (from $650 \mathrm{~m}$ to $1420 \mathrm{~m}$ a.s.l.). Geologically, the Bavarian Forest is on the south-western part of the Bohemian Massif (Variscian basement), which consists mainly of granite and gneiss. Consequently, soils are acidic, sandy and loamy (particularly brown earths and podsols) and partly covered with rocks. At all altitudes, but especially in the valleys, there is characteristically a persistent or intermittent water-table in both mineral and organic soils (Bässler et al. 2009). On a larger scale, the Bavarian Forest belongs to the temperate zone and subject to both atlantic and continental influences. The total annual precipitation is between 1200 and $1800 \mathrm{~mm}$ depending on altitude. Annual mean air temperature varies between $5.1^{\circ} \mathrm{C}$ in the valleys, $5.8^{\circ} \mathrm{C}$ on hillsides and $3.8{ }^{\circ} \mathrm{C}$ in the high montane zones (Noack 1979; Bässler 2004).

The first survey of the study area was done during the summer of 2011. After a discussion with the Bavarian Forest NP Authority, "Nationalparkstrasse", a main road in the eastern part of the Bavarian Forest NP and two roads running tangentially to the Nationalparkstrasse to Waldhäuser and Racheldienesthütte were chosen to be studied in this project (Fig. 1).

\section{Data collection}

Nine permanent study sites were established in the study area, seven of which were located along roads where deicing salts were regularly applied (the main road Nationalparkstrasse and the road to Waldhäuser). Two of the study sites were along roads that were not salted and they were used as control sites. All sites were provided with blue permanent markers, had their GPS positions recorded (Table 1) and photographed.

Rules and principles of salting and the amount of salt applied in the study area were discussed with the Landratsamt Freyung-Grafenau office, which is responsible for the maintenance of the roads.

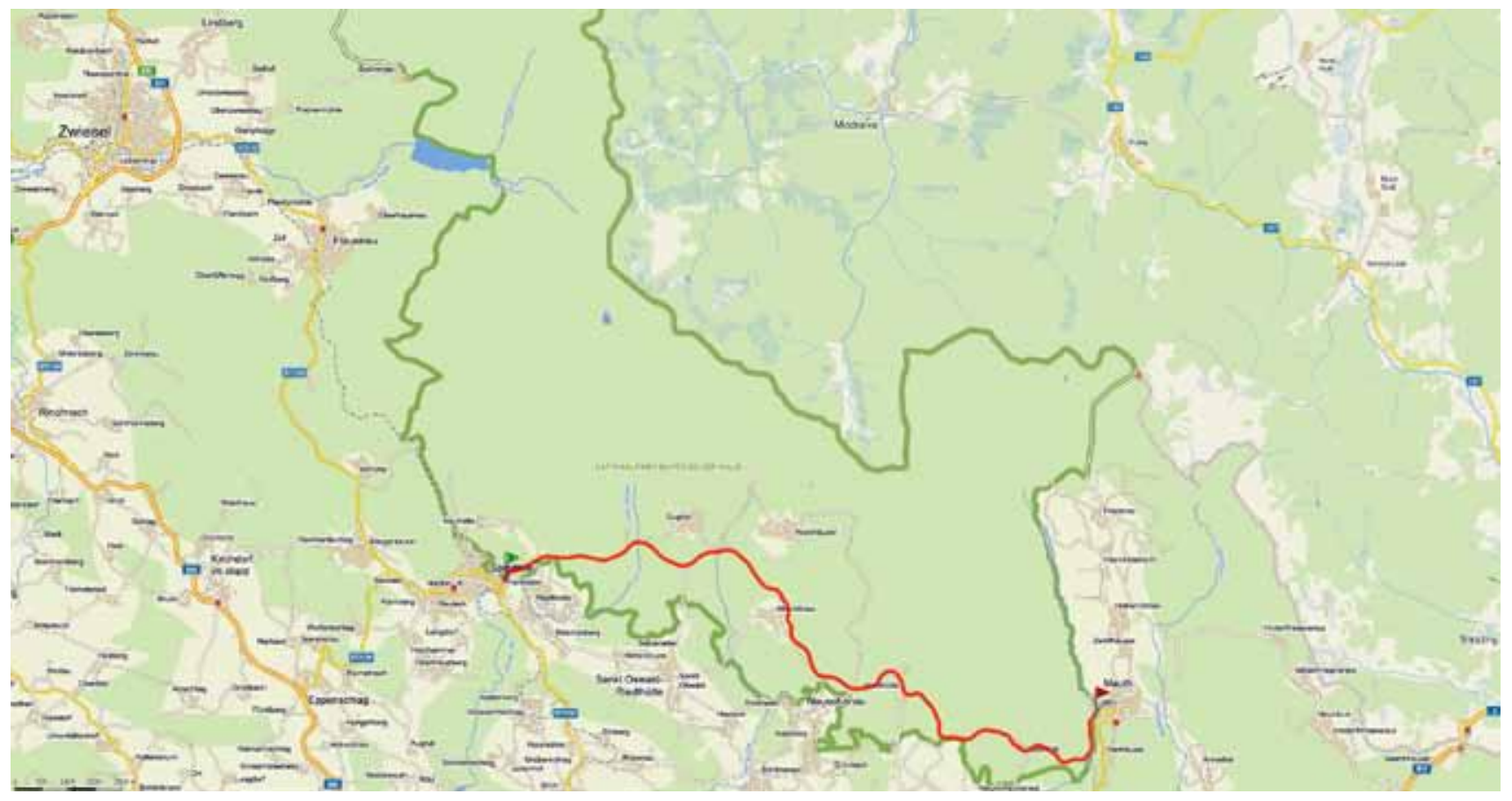

Fig. 1 The study area. The main road "Nationalparkstrasse" is marked by a red line (http://www.mapy.cz). 
Table 1 The study sites and their geographical characteristics.

\begin{tabular}{|c|c|c|c|c|}
\hline Site \# & Name & GPS & Altitude $\mathrm{m}$ a.s.l. & Salt $+I-$ \\
\hline 1 & Mauth - main road & N48 53.118 E13 34.522 & $772 m$ & + \\
\hline 2 & Mauth - control & N48 53.218 E13 34.551 & $773 m$ & - \\
\hline 3 & Racheldiensthütte & N48 55.401 E13 24.644 & $773 m$ & - \\
\hline 4 & Grosse Ohe - west & N48 55.416 E13 24.862 & $765 m$ & + \\
\hline 5 & Grosse Ohe - east & N48 55.406 E13 24.817 & $764 m$ & + \\
\hline 6 & Waldhäuser & N48 56.237 E13 27.288 & $847 m$ & + \\
\hline 7 & Grosse Filz & N48 55.338 E13 25.210 & $777 m$ & + \\
\hline 8 & Guglöd & N48 55.388 E13 25.106 & $769 m$ & + \\
\hline 9 & Altschönau & N48 54.664 E13 27.977 & $748 m$ & + \\
\hline
\end{tabular}

Soil conditions were recorded at all the study sites at distances of 5 and 10 meters from the road edge. Samples of soil were collected from the upper $(0 \mathrm{~m}$ to $-0.10 \mathrm{~m})$ and lower soil layers $(>-0.10 \mathrm{~m})$ at four sample points and then samples from each soil horizon mixed for each site. The mixed soil samples for each site were analyzed by the certified laboratory in Klatovy (The Health Institute Pilsen, Laboratory Klatovy). The same laboratory also measured the characteristics of the deicing material applied to the roads in the Sumava NP.

Following parameters were measured: after water extraction: $\mathrm{pH}_{\mathrm{H} 20}, \mathrm{Na}^{+}, \mathrm{Cl}^{-}, \mathrm{SO}_{4}{ }^{2-}$, conductivity; $\mathrm{pH}_{\mathrm{KCl}}$; Moehlich II: $\mathrm{Ca}^{2+}, \mathrm{Mg}^{2+}, \mathrm{K}^{+}, \mathrm{Na}^{+}$.

Each soil sample was marked with a specific code:

The first $\quad$ S 321 is the site number

The second S321 the distance from the edge of the road: $1=5 \mathrm{~m}, 2=10 \mathrm{~m}$

The third

S321 the layer of soil sampled: 1 = upper $10 \mathrm{~cm}, 2=$ deeper than $10 \mathrm{~cm}$

Two five-meters long transects were laid out at each site in August 2011 in order to identify the plants occurring there. These transects ran parallel with the road. The first one was located just at the edge of the asphalt road surface and the second one meter from the road edge. In addition, if necessary, another transect was established to record the vegetation at a distance five meters from the road edge using the standard method used for all the transects, which was based on five levels of abundance for each species (Braun-Blanquet 1951). Also percentage cover of mosses, herbaceous plants, shrubs and trees were recorded along all transects. The species occurrences and their salt-tolerance were studied.

Three categories of species were distinguished (Ellenberger et al. 1992):

- Halophytes $=$ species that tolerate and thrive on substrates with a high salinity;
- Sub-halophytes = species that can tolerate moderate salinity but not a high salinity;

- Glycophytes = species that are very susceptibe and easily damaged by saline conditions.

Transects were characterized by the percentages of halophytes, sub-halophytes and glycophytes. Necrosis, leaf senescence and other forms of damage were recorded.

Floristic terminology follows Kubát et al. (2002).

\section{Results}

Landratsamt Freyung-Grafenau, the official authority responsible for maintaining the roads, informed us that only rock salt $\mathrm{NaCl}$ is used for deicing roads in the Bavarian Forest NP. No salt solutions, sprays or any other additional agents are applied. The standard amount of deicing salt depends on climatic conditions and varies from $10 \mathrm{~g} / \mathrm{m}^{2}$ to $40 \mathrm{~g} / \mathrm{m}^{2}$. During the winter 2010/2011 a total of 233.5 tons of salt were scattered along the main road "Nationalparkstrasse", which is 23 kilometers long.

\section{Soil}

Soil profiles were studied at sites \# 4, 5 and 7 (Table 2) and the soil samples collected at four sites: \# 3, 4, 5 and 7 were analyzed chemically. There were no significant differences in the $\mathrm{pH}$ of the soil samples from the different sites. The $\mathrm{pH}$ of the samples $(\mathrm{S} 321=3.2, \mathrm{~S} 322=4.14)$ from the control site \# 3 (Fig. 2) was slightly lower and their conductivity, along with that of S421 and S422, were also higher (Fig. 3).

Significant differences in the concentrations of $\mathrm{Cl}^{-}$and $\mathrm{Na}^{+}$ions were recorded. The highest concentrations of both ions were recorded in samples from site \# 4 - Grosse Ohe west. Especially samples S421 and S422, which were collected at a distance of ten meters from the road edge (Fig. 4). The same trends were recorded also using the Moehlich $\mathrm{Na}^{+}$testing method. 
Table 2 Soil profiles and their characteristics at sites \# 4,5 and 7. Sample 1 was located five meters from the edge of the road and sample 2 ten meters from the edge.

\begin{tabular}{|l|c|c|l|}
\hline & Sample & Depth & \\
\hline Site \# 4 & 1 & $0-0.05 \mathrm{~m}$ & sandy soil, grey-black, humic \\
\hline & & $0.05-0.7 \mathrm{~m}$ & loamy sand soil, grey, locally red spots, lower more clay - flooded alluvium \\
\hline & & $>0.7 \mathrm{~m}$ & grey-black clay \\
\hline & 2 & $0-0.05 \mathrm{~m}$ & sandy soil, grey-black, humic \\
\hline & & $0.05-0.3 \mathrm{~m}$ & shallow grey sandy clay \\
\hline Site \# 5 & 1 & $0-0.3 \mathrm{~m}$ & gray-green sandy soil, red-rusty glay; with paragneiss debris - probably periodically flooded alluvium \\
\hline & & $>0.3 \mathrm{~m}$ & gravel and stones \\
\hline & 2 & $0-0.2 \mathrm{~m}$ & sandy soil, black to grey-black, humic \\
\hline & & $0.2-0.6 \mathrm{~m}$ & grey stony sand - periodically flooded alluvium and buried humic horizon \\
\hline Site \# 7 & 1 & $0-0.05 \mathrm{~m}$ & gray-brown clay, slightly humic, partly decomposed litter \\
\hline & & $0.05-0.4 \mathrm{~m}$ & strongly sandy soil, brown, with paragneiss debris \\
\hline & & $>0.5 \mathrm{~m}$ & permanently waterlogged \\
\hline & 2 & $0-0.05 \mathrm{~m}$ & gray-brown clay, slightly humic, partly decomposed litter \\
\hline & & $0.05-0.4 \mathrm{~m}$ & strongly sandy soil, red-brown, paragneiss debris \\
\hline
\end{tabular}

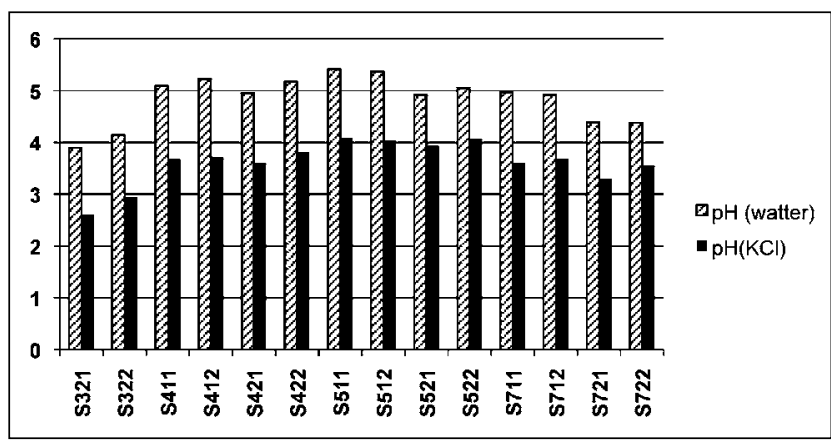

Fig. 2 The $\mathrm{pH}$ levels recorded for soil samples collected from the different sites.

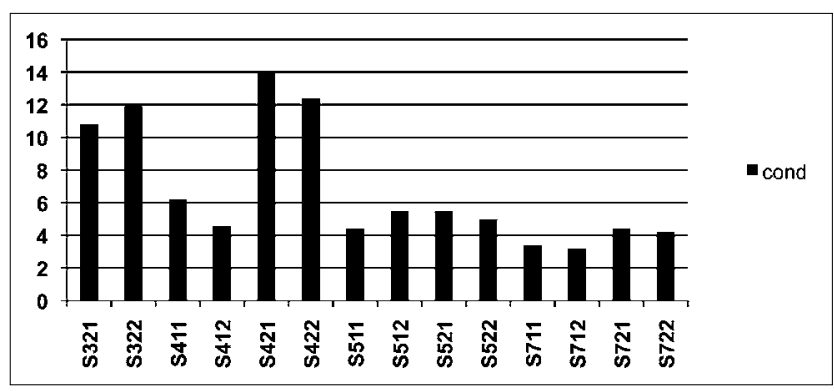

Fig. 3 Conductivities recorded for the soil samples collected from the different sites.

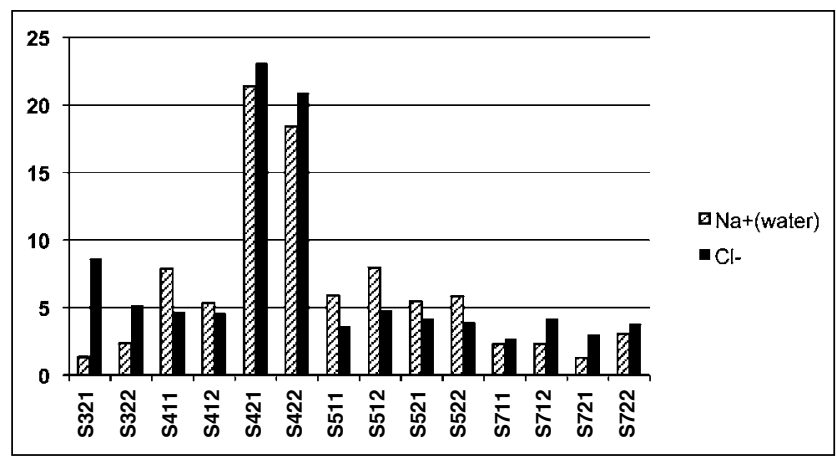

Fig. 4 Concentrations of $\mathrm{Na}^{+}$and $\mathrm{Cl}^{-}$ions recorded in soil samples.

\section{Vegetation}

Two transects, the first one at the edge of the road and the second one meter distance from the edge, were established at seven study sites (Table 3 ). Additional transects were established at two study sites ( 4 and 5 ) to record the differences in vegetation cover at a distance of five meters from the road edge. Numbers of species recorded in the additional transects were very low. Mosses were recorded only in eight transects and no shrubs and trees were recorded in any transect.

Results of the vegetation survey along transects revealed that significantly higher numbers of halophytes and sub-halophytes occurred near the Grosse Ohe River. The highest number was recorded at site \# 4 where twelve and eleven halophytes and sub-halophytes, respectively, were recorded in both the transects at this site (S4_1 = at the edge of the road, S4_2 = one meter from the edge of the road; Table 3). No halophytes were recorded in the additional transect at this site, where only Calamagrostis villosa and Carex brizoides occurred. Seven halophytes and sub-halophytes occurred in the first transects at sites

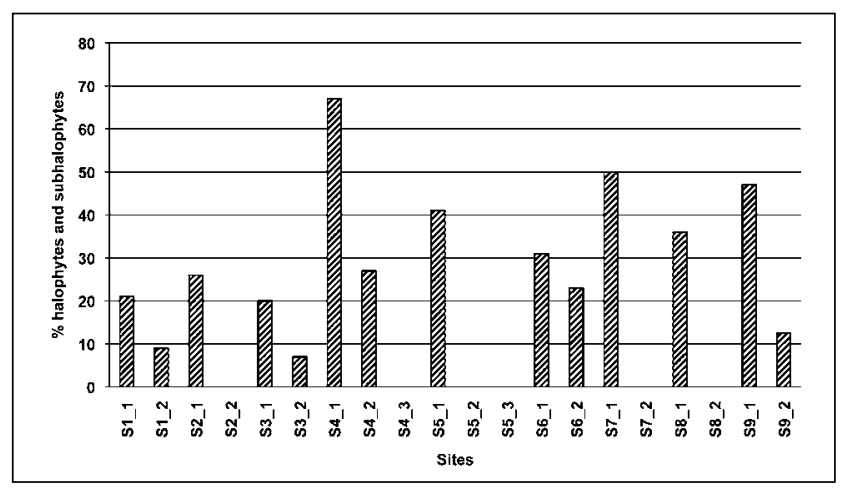

Fig. 5 Percentages of halophytes and sub-halophytes recorded along the different transects. 
Table 3 Study sites and percentage vegetation cover recorded along the different transects. The first transects at each site were located at the edge of the road and the second at a distance of one meter from the edge. Transects S4_3 and S5_3 were at a distance of five meters from the road.

Percentage vegetation cover of mosses (E0) and herbaceous plants (E1) were recorded. No shrubs (E2) or trees (E3) were recorded. Tota numbers of species recorded along each transect and the numbers of halophytes and sub-halophytes $(\mathrm{H}+\mathrm{SH})$ are listed.

\begin{tabular}{|c|c|c|c|c|c|c|c|}
\hline Site \# & Name & transect & $E_{0}$ & $E_{1}$ & species & $\mathbf{H}+\mathbf{S H}$ & $(\mathrm{H}+\mathrm{SH}) / \mathrm{G}$ \\
\hline \multirow[t]{2}{*}{1} & Mauth - main road & S1_1 & 30 & 55 & 19 & 4 & 21 \\
\hline & & S1_2 & 50 & 100 & 11 & 1 & 9 \\
\hline \multirow[t]{2}{*}{2} & Mauth - control & S2_1 & 0 & 100 & 19 & 5 & 26 \\
\hline & & S2_2 & 0 & 100 & 12 & 0 & 0 \\
\hline \multirow[t]{2}{*}{3} & Racheldiensthütte & S3_1 & 90 & 55 & 10 & 2 & 20 \\
\hline & & S3_2 & 90 & 100 & 14 & 1 & 7 \\
\hline \multirow[t]{3}{*}{4} & Grosse Ohe - west & S4_1 & 0 & 50 & 12 & 8 & 67 \\
\hline & & S4_2 & 40 & 100 & 11 & 3 & 27 \\
\hline & & S4_3 & 0 & 100 & 4 & 0 & 0 \\
\hline \multirow[t]{3}{*}{5} & Grosse Ohe - east & S5_1 & 5 & 70 & 17 & 7 & 41 \\
\hline & & S5_2 & 40 & 100 & 3 & 0 & 0 \\
\hline & & S5_3 & 0 & 100 & 2 & 0 & 0 \\
\hline \multirow[t]{2}{*}{6} & Waldhäuser & S6_1 & 0 & 60 & 13 & 4 & 31 \\
\hline & & S6_2 & 0 & 70 & 13 & 3 & 23 \\
\hline \multirow[t]{2}{*}{7} & Grosse Filz & S7_1 & 0 & 80 & 12 & 6 & 50 \\
\hline & & S7_2 & 10 & 100 & 7 & 0 & 0 \\
\hline \multirow[t]{2}{*}{8} & Guglöd & S8_1 & 0 & 70 & 14 & 5 & 36 \\
\hline & & S8_2 & 15 & 80 & 10 & 0 & 0 \\
\hline \multirow[t]{2}{*}{9} & Atlschönau & S9_1 & 0 & 80 & 15 & 7 & 47 \\
\hline & & S9_2 & 40 & 80 & 8 & 1 & 12.5 \\
\hline
\end{tabular}

\# 5 and 9 . Higher percentages (> 30\%) of halophytes and sub-halophytes were recorded also in the first transects at sites \# 7,8 and 9 (Fig. 5). All of these sites were located at several-kilometer intervals along the main road " $\mathrm{Na}$ tionalparkstrasse".

The most often recorded halophytes and sub-halophytes were:

- Juncus bufonius - toad rush - grows in moist and muddy places and is considered to be a weed in many areas. This annual species has some tolerance of salinity;

- Matricaria discoidea - pineapple weed - this American species has successfully colonized many biotopes in Europe, especially those with high levels of nutrients;

- Plantago coronopus - buck's horn plantain - a halophyte native to the Mediterranean, which seldom occurs in Central Europe. High abundances of this species were recorded along transects at the road edges at sites number 4 and 5, where this species was dominant along with Sagina procumbens and Puccinelia distans;

- Poa annua - annual bluegrass - this annual species is moderately tolerant of salinity. Together with Matricaria discoidea, Plantago major and Polygonum aviculare are also tolerant of trampling;

- Puccinellia distans - weeping alkali-grass - this species is a native of Europe and occurs in most of North America. Also anthropogenic habitats in many places in Europe are colonized secondarily by this species. It grows in moist habitats, usually in areas with saline soils, such as along the edges of salted roads;

- Ranunculus repens - creeping buttercup - this stoloniferous perennial plant is a native of Europe, Asia and northwestern Africa. It grows prostrately at the sides of roads and often is spread by traffic;

- Sagina procumbens - procumbent pearl-wort - this species has a circumpolar distribution and occurs as a native plant in both North America and Eurasia. This species has a high tolerance of trampling or mowing and frequently colonizes disturbed locations;

- Sonchus asper - spiny sow thistle - this annual plant species is a native of Europe and a common weed in North America. This species often occurs along roads and in agriculture landscapes;

- Spergularia salina - saltmarsh sand-spurry - this annual halophyte has recently spread along salted roads. This species is a native of sea-shores, shore side meadows and other salty locations;

- Trifolium repens - this perennial plant is a native of Europe, North Africa and West Asia, and is frequently found growing in lawns and areas subject to trampling. No necrotic areas or structures were recorded on the plants growing along any of the transects but the young spruces growing close to sites \# 8 and 9 were affected by spray containing deicing salts coming from the road. 


\section{Conclusions and recommendation}

Nine permanent study sites were established. The results of this preliminary study showed that the methods used to describe the current ecological conditions along the main roads and at control sites in the eastern part of the Bavarian Forest NP, where deicing salt is regularly applied, were appropriate.

We found that the soils collected from the different sites differed significantly in their chemical parameters. The highest amount of $\mathrm{Na}^{+}$and $\mathrm{Cl}^{-}$ions were recorded at site \# 4, which is located only several meters from the bank of the Grosse Ohe River. Much higher concentrations of $\mathrm{Na}^{+}$and $\mathrm{Cl}^{-}$ions were found 10 meters from the edge of the road than at the road edge and it is assumed that this because this location is subject to long-term contamination due to the accumulation of water there from melting snow. It is important that the trajectories of the mobility of ions, including seasonal variability, should be studied. Also there are indications that there are higher concentrations of salt ions at other sites along the main road, especially between Altschönau and Spiegelau. High concentrations of salt ions were usually recorded in samples collected five meters from the road edge.

A high conductivity together with a high concentration of $\mathrm{Cl}^{-}$ions were recorded also in samples collected at site \# 3, a control site far from where the rock salt is applied. It is likely that this is due some specific anthropogenic history of that site but more research on the soil characteristics is needed to resolve this.

The vegetation analyses revealed significant difference in the occurrence of halophytes and sub-halophytes at the different sites. The highest numbers of halophytes and sub-halophytes were recorded at sites \# 4, 5, 7, 8 and 9 along the main road between Altschönau and Spiegelau.

Puccinellia distans, Sagina procumbens, Spergularia salina and Plantago coronopus, the most common halophytes, were very abundant at the edges of the roads at some places. Plantago coronopus has not yet been recorded in the Šumava NP. Occurrence of several other dominant species of plants should be studied also in context of other road management practices, i.e., trampling and road side mowing. The road management practices in the Bavarian Forest NP and Šumava NP (Hošek and Kaufman 1992; Pyšek and Zýval 1993; Zýval et al. 1999a,b) differ.

\section{Acknowledgements}

We thank the following institutions and persons: The Health Institute Pilsen, Laboratory Klatovy for chemical analyses, V. Zýval jun. for help with soil sampling and other field work, A. Dixon for revising the language, two referees for their valuable comments, and the Bavarian Forest NP Authority for providing the financial support.

\section{REFERENCES}

Angold PG (1997) The impact of a road upon adjacent heathland vegetation: effects on plant species composition. J Appl Ecol 34: 409-417.

Bässler C, Förster B, Moning Ch, Müller J (2009) The BIOKLIM Project: Biodiversity Research between Climate Change and Wilding in a temperate montane forest - The conceptual framework. Waldökologie, Landschaftsforschung und Naturschutz, Heft 7, pp 21-34.

Bässler C (2004) Das Klima im Nationalpark Bayerischer Wald Darstellung, Entwicklung und Auswirkung. Nationalparkverwaltung Bayerischer Wald.

Braun-Blanquet J (1951) Pflanzensoziologie. 2nd ed. Wien.

Denoel $\mathrm{M}$ et al (2010) Cumulative effects of road de-icing salt on amphibian behavior. Aquatic Toxicology 99: 275-280.

Ellenberg H, Weber HE, Düll R, Wirth V, Werner W, Paulißen D (1992) Zeigerwerte von Pflanzen in Mitteleuropa. Scripta geobotanica, E. Goltze Ver., Göttingen.

Elling W, Bauer E, Klemm G, Koch H (1987) Klima und Böden. Nationalparkverwaltung Bayerischer Wald.

Hošek J, Kaufman R (1992) Vliv kamionové dopravy a zimní údržby silnice E-53 na př́rodu Národního parku Šumava a na životní prostředí centrální části sídla Železná Ruda. MS Agnos Praha.

Karraker NE, James PG, James RV (2008) Impacts of road deicing salt on the demography of vernal pool-breeding amphibians. Ecol Appl 18: 724-734.

Kubát K (ed) (2002) Klíč ke květeně České republiky. Academia, Praha.

Noack EM (1979) Witterung und Klima im Bayerischen Wald. Nationalparkverwaltung Bayerischer Wald.

Oberdorfer E (1983) Pflanzensoziologische Excursionsflora. E. Ulmer Ver., Stuttgart.

Pyšek A, Zýval V (1993) Vliv zimní údržby silnice I/4 na okolní přírodní ekosystémy. MS Gekon, Praha.

Rusek J, Rusek J (1999) Impact of winter road salting on soil Collembola and other microarthropods. The conference report: Soil Zoology in Central Europe, České Budějovice.

Smolík L (1957) Pedologie. SNTL, Praha.

Wrobel M, Tomaszewicz T, Chudecka J (2006) Floristic diversity and spatial distribution of roadside halophytes along forest and field roads in Szczecin lowland (West Poland). Pol J Ecol 54: 303-309.

Zýval V, Pyšek A, Chocholoušková Z, Hájek M (1999a) Silnice I/4, I/27 a II/141. Hodnocení vlivu zimní údržby na kontaktní ekosystémy v NP a CHKO Šumava (I. část - půdy). MS GeoVision, Plzeň.

Zýval V, Pyšek A, Chocholoušková Z, Hájek M (1999b) Silnice II/141. Hodnocení vlivu zimní údržby na kontaktní ekosystémy v NP a CHKO Šumava (II. část - vegetace). MS GeoVision, Plzeň. 